\title{
ГРАЖДАНСКО-ПРАВОВОЙ АСПЕКТ ВОЕННОГО ПРАВА: НЕКОТОРЫЕ ВОПРОСЫ ТЕОРИИ
}

\begin{abstract}
Аннотация: Цель: на основе анализа различных подходов к месту и роли военного права в правовой системе России, а также рассмотрения особенностей участия военных организаций и военнослужащих в гражданском обороте определить возможность межотраслевого (военно-правового и гражданско-правового) регулирования отнотений в области обеспечения военной безопасности России.Объект: общественные отношения, возникающие в связи с осуществлением военнослужащими и военными организациями деятельности по обеспечению военной безопасности России на современном этапе развития Вооруженных Сил Российской Федерации. Предмет: нормы права, правовые конструкиии и правовые средства, при-меняемые в сфере обеспечения военной безопасности государства. Методы исследования: общенаучные методы познания (анализ, синтез, обобщение, системно-структурныйметод), а также логический и формально-юридический методы научного исследования. Результаты: выработаны направления решения проблемы межотраслевого (военно-правового и гражданскоправового) регулирования отношений в сфере обеспечения военной безопасности государства.Практическое значение: положение и выводы, сформулированные в статье, вносят определенный вклад в развитие правовой системы России, гражданского и военного права, а также науки военного права.
\end{abstract}

Abstract: Based upon the analysis of various approaches to the place and role of military law in the legal system of the Russian Federation and the evaluation of the participation of military organizations and military officers in the civil law turnover, the author establishes the possibility for the interdisciplinary (military law and civil law) regulation of the relations in the sphere of guarantees of military security of the Russian Federation. The object of studies includes social relations, which appear in regard with the implementation of the activities for the guarantees of military security of the Russian Federation by the military officers and military organizations at the current stage of development of the Armed Forces of the Russian Federation. The immediate object includes norms of law, legal constructions and legal means used in the sphere of guarantees of military security of the state. The methods of study include general scientific cognition methods (analysis, synthesis, generalization, systemic structural method), as well as logical and formal legal methods for the scientific research. The results include the development of the directions for solving the problems of interdisciplinary (military law and civil law) regulation of the relations in the sphere of guarantees of military security of the state. Its practical value is due to the fact that the conclusions and provisions formulated in this article have an impact on the development of legal system of the Russian Federation, its civil and military law, as well as the science of military law.

Ключевые слова: Военная безопасность, Система права, Военное право, Комплексная отрасль права, Межотраслевой правовой институт, участники гражданско-правовых отношений, Военнослужащие, военные организации, гражданско-правовое регулирование, военная безопасность государства

Keywords: military security, system of law, military law, complex branch of law, interdisciplinary legal institution, participants of civil law relations, military officers, military organizations, civil law regulation, military security of the state.

оссия вступила на путь правового развития, становления гражданского общества, процесс формирования и осуществления правовой демократической политики государства намного позже иных государств Западной Европы. Российским обновленным общественной, экономической и правовой системам немногим более 20 лет. Перед нашей страной стоит сложная задача перестройки стержневого элемента правовой системы России - права, роль которого в жизни общества трудно переоценить. Отражая назревшие социальные потребности, право, с одной стороны, вынужденно «подстраиваться» под них, своевременно их отражать, а с другой, само выступает инструментом, с помощью которого возможно наиболее действенно провести в жизнь необходимые преобразования. Именно на основе грамотно построенной правовой политики, при 
умелом использовании юридических средств, как универсальных регуляторов широкого спектра социальных связей, сегодня возможно осуществить наиболее цивилизованное и результативное формирование правового государства, построение гражданского общества и обеспечение национальных интересов России.

Национальные интересы России представляют собой «совокупность сбалансированных интересов личности, общества и государства в экономической, внутриполитической, социальной, международной, информационной, военной, пограничной, экологической и других сферах жизнедеятельности. Как правило, они носят долгосрочный характер и определяют основные цели, стратегические и текущие задачи внутренней и внешней политики российского государства». Стратегические задачи нашего государства определены в Стратегии национальной безопасности Российской Федерации до 2020 года, утвержденной Указом Президента Российской Федерации от 12 мая 2009 года № $537^{2}$. В соответствии с указанным документом, основными приоритетами национальной безопасности России являются национальная оборона, государственная и общественная безопасность ${ }^{3}$. Согласно п. 6 Военной доктрины Российской Федерации, утвержденной Указом Президента Российской Федерации от 5 февраля 2010 года № 146 (далее по тексту, - Военная доктрина) 4 под военной безопасностью Российской Федерации понимается состояние защищенности жизненно важных интересов личности, общества и государства от внешних и внутренних угроз, связанных с применением военной силы или угрозой ее применения, характеризуемое отсутствием военной угрозы либо способностью ей противостоять.

Военная безопасность обеспечивается силами и средствами, которые находятся в распоряжении государства. Одно из основных мест среди них занимает военная организация государства. Военная организация государства, как определено в Военной доктрине, включает совокупность органов государ-

\footnotetext{
${ }^{1}$ Основы социологии: учебное пособие /под ред. М.В. Прокопова - М.: Русская дел. литература, 2003. С. 172.

2 Указ Президента РФ от 12 мая 2009 г. N 537 «О Стратегии национальной безопасности Российской Федерации до 2020 года» // Собрание законодательства РФ, 18.05.2009, № 20, ст. 2444.

${ }^{3}$ Там же.

${ }^{4}$ Указ Президента Российской Федерации от 05.02.2010 г. № 146 «О Военной доктрине Российской Федерации» // Собрание законодательства Российской Федерации. 2010. № 7. Ст. 724. П. 6. подп. «д».
}

ственного и военного управления, Вооруженных Сил Российской Федерации, других войск, воинских формирований и органов, составляющих ее основу и осуществляющих свою деятельность военными методами, а также части производственного и научного комплексов страны, совместная деятельность которых направлена на подготовку к вооруженной защите и вооруженную защиту Российской Федерации 5 . Теоретики военного права определяют военную безопасность с юридической точки зрения, которая представляет собой комплексный правовой институт со специфическим содержанием, включающим в себя обороноспособность и оборону, и является юридически исходным правовым средством в системе построения национальной безопасности, ибо он включает в себя правовой материал, который обеспечивает функционирование самого государства. Он состоит из первичных единичных юридических положений правовых норм, устанавливающих многочисленные и разнообразные по характеру и значимости государственные, общественные и личностные отношения в сфере обеспечения военной безопасности ${ }^{6}$.

Правовое регулирование в области обеспечения военной безопасности осуществляется в основном военным правом, которое упорядочивает отношения военной деятельности государства, а также военнослужебные отношения. Военное право представляет собой систему установленных государством общеобязательных правовых норм, закрепляющих формы устройства и принципы функционирования военной организации государства и обеспечения его военной безопасности, регулирующих отношения в области строительства и комплектования Вооруженных Сил, других войск, воинских формирований и органов, их материально-технического обеспечения, жизни, быта, деятельности и определяющих порядок прохождения военной службы, а также статус (права, обязанности, ответственность) военнослужащих и других участников военных правоотношений ${ }^{7}$.

Исходя из приведенных выше определений военной безопасности и военного права, следует вывод, что деятельность военной организации государства по осуществлению возложенных на нее задач включает в себя широкий спектр отношений, урегулирование

\footnotetext{
${ }^{5}$ См. там же п. 6. подп. «к».

${ }^{6}$ Военное право: Учебник. Серия «Право в Вооруженных Силах - консультант». М.: «За права военнослужащих», 2004. Вып. 45. 640 c. C. 55.

${ }^{7}$ Военное право / под ред. А.Я. Петроченкова. М.: Норма, 2007. с.5
} 


\section{Право и политика $3(171) \cdot 2014$}

которых силами и средствами только военного права видится проблематичным.

Так, в целях повышения качественного состояния Вооруженных Сил проводится работа по оснащению войск современным вооружением и техникой, строительству инфраструктуры для их эксплуатации, подготовки специалистов, создания необходимой учебно-материальной базы и фонда служебного жилья. В 2013 году Министерством обороны принята новая имущественная политика. Пересмотрены подходы к аутсорсингу ${ }^{8}$.

29 января 2013 года на встрече с Верховным Главнокомандующим глава военного ведомства заявил, что Россия должна иметь весь арсенал средств и возможностей, которые позволят стране ответить на любые вызовы. Для этого, по словам С.К. Шойгу, нужны эффективные Вооруженные силы, методы управления ими, современное вооружение, новая военная техника и качественно обученные кадры ${ }^{9}$.

Следовательно, на отрасль военного права возложена серьезная задача по урегулированию широкого круга правоотношений, упорядочение которых невозможно без привлечения средств других отраслей права, в частности, гражданского права. К таким правоотношениям, например, относятся: организация деятельности военной организации государства в условиях рыночных отношений, обеспечение и защита прав и свобод военнослужащих в мирное время, так и отчасти правовое сопровождение деятельности воинских формирований в военное время.

Многие авторы ${ }^{10}$ сходятся во мнении о том, что отрасль военного права является комплексной, «в

\footnotetext{
${ }^{8}$ Официальный сайт Президента России : Стенограмма расширенного заседания коллегии Минобороны. URL: http://www.kremlin. ru/transcripts/19816 (дата обращения: 21.01.2014).

9 Военно-политическое обозрение: электрон. версия жур. 2013. http://topwar.ru/23582-shoygu-i-gerasimov-predstavili-prezidentu-planoborony-strany-otkuda-ishodyat-glavnye-opasnosti-dlya-rossii.html

${ }^{10}$ См., например: Ахметшин Х.M. Военно-уголовное законодательство в системе военного права // Российский военно-правовой сборник. 2004. № 1. С. 86-87; Ахметшин Х.М. Военно-уголовное законодательство Российской Федерации // Военно-уголовное законодательство Российской Федерации: Научно-практический комментарий / Под ред. Н.А.Петухова. М., 2004. С. 8-23; Орлов Г.В. О структуре советского военного законодательства // 40 лет военно-юридическому образованию в СССР. Сборник статей. М., 1977. С. 191-201; Орлов Г.В. Предмет регулирования комплексной отрасли советского законодательства // Сборник статей Военного Краснознаменного института. М., 1985. № 21. С. 194-200; Военное право: Краткий учебный курс / Под ред. А.Я. Петроченкова. М., 2006; Военное право: Учебник / Под ред. В.Г. Стрекозова, А.В. Кудашкина. М., 2004; Мигачев Ю.И., Тихомиров С.В. Военное право. М., 2005. и др.
}

которую наряду с иерархически выстроенными по вертикали (исходя из критерия юридической силы правовых актов) нормами военного законодательства, регулирующими вопросы военной деятельности государства и военно-служебные отношения, входят нормы, относящиеся к другим (классическим, т.е. традиционным) отраслям законодательства-административному, гражданскому, финансовому, жилищному, земельному, уголовному и др. ${ }^{11}$

П.И. Романов определял военное право как систему установленных государством правовых норм, закрепляющих принципы и формы устройства вооруженных сил, регулирующих отношения в области их строительства, жизни, быта и деятельности и определяющих обязанности, права и ответственность военнослужащих и других участников воинских отношений ${ }^{12}$. При этом автор подчеркивал, что военное право представляет собой комплексное правообразование и включает в себя нормы различных «традиционных» отраслей права, имеющих предметное единство, состоящее в правовом регулировании общественных отношений в области военного строительства в стране.

На наш взгляд, возникновение комплексных правовых отраслей является неизбежным результатом естественного эволюционного развития права. Современные реалии изменились, появились и продолжают появляться новые сферы общественных отношений, которые невозможно регулировать нормами одной отрасли права. И в этой ситуации юридическая наука должна быть гибкой, чтобы оставаться эффективной. Существующие общественные отношения как предмет правового регулирования невозможно искусственно «подогнать» под действующие нормы права. Нормы права должны постоянно адаптироваться и актуализироваться в соответствии с меняющимися условиями жизни общества.

Противники обозначенной выше позиции полагают, что высказывания сторонников наличия в системе права наряду с основными отраслями комплексных отраслей основаны на смешении системы права с системой законодательства в целом либо с системой отдельных законодательных актов. Система права не

\footnotetext{
${ }^{11}$ Толкаченко А.А., Современное состояние военно-юридической (военно-правовой) науки и ее роль в укреплении безопасности России. Журнал «Право и безопасность» Номер - 3- 4 (24-25), Декабрь 2007.

12 Романов П.И. Военное право как отрасль советского законодательства, учебная и научная дисциплина // Вопросы теории военного законодательства и практики его применения. - М., 1974. - C. $22-43$.
} 
слагается, не образуется из системы законодательных актов. Система права - социальная реальность, в которой юридически отражается структура регулируемых правом общественных отношений. Что же касается комплексных отраслей, то они суть не отрасли права, а произвольные (исходя из тех или иных научных, педагогических или практических соображений), субъективно сформированные группы норм права, принадлежащие к отдельным отраслям системы права в целом либо к отдельным правовым институтам системы, конкретной отрасли права в частности ${ }^{13}$.

Так, К.В. Каверин утверждает, что военное право является подотраслью административного права. По мнению указанного автора, исследование ряда работ в области военного и административного права позволяет сделать вывод о том, что у названных областей правового регулирования есть достаточно схожих черт в объекте, предмете и механизме реализации норм права. Исключение составляют средства их реализации, которые у военного права весьма специфичны и представляют собой использование военной силы (люди, обладающие специальным правовым статусом - военнослужащие; вооружение; военная техника), особый порядок функционирования военной организации, а также государственного обеспечения ее деятельности и т.п.

С.С. Алексеев писал: «Если оставаться в пределах фактов реальной действительности, если не заниматься произвольным конструированием комплексных отраслей, то нельзя не признать, что все те совокупности норм, которые в литературе причислялись к комплексным отраслям (транспортное право, морское право, страховое право, банковское право и др.), на самом деле не являются подразделениями объективно существующей системы права. Все они относятся либо к отраслям законодательства, либо к отраслям правовой науки» ${ }^{14}$. Отвергая существование комплексных отраслей права, С.С. Алексеев вместе с тем подробно обосновал весьма плодотворный для познания путей развития системы права тезис о наличии в системе права комплексных (смешанных) правовых институтов ${ }^{15}$.

\footnotetext{
${ }^{13}$ См.: Красавчиков О.А. Советская наука гражданского права (понятие, предмет, состав и система). Учен. труды Свердловского юрид. ин-та, т.6. Свердловск, 1961, с.250, 251, 258 - 263;

${ }^{14}$ Алексеев С.С. Общие теоретические проблемы системы советского права. М, 1961, с.93 -101.

${ }^{15}$ См. тамже, с.82 - 93. О наличии в системе советского права смешанных институтов писал еще М.М. Агарков (см.: Агарков М.M. Предмет и система советского гражданского права. - «Советское государство и право», 1940, № 8 - 9, с.4 - 5). Признавал существование смежных (сложных) правовых институтов, отрицая в то же время наличие комплексных отраслей права, и И.В. Павлов (см.: Павлов И.В. О системе
}

Д.М. Азми не считает обоснованным «выделение комплексных «отраслей» права (по причине отсутствия в данном направлении необходимых для проведения последовательной градации признаков). У комплексных «отраслей» отсутствует хотя бы относительно (условно) обособленный («самостоятельный») предмет правового регулирования. При этом признание необходимости одних, называемых показательными, критериальными (пусть и в условном смысле), свойств у некоторых отраслей и постулирование возможности отсутствия этих же свойств у иных отраслей, нивелируют ценность отраслевого деления, ликвидируют его информативные, практические и познавательные характеристики. При подобном подходе отраслью права может быть назван вообще фактически любой представленный юридическими нормами массив. ... В свою очередь, выделение комплексной (межотраслевой, смешанной, а еще точнее, интегрированной) разновидности институтов (как законодательства, так и права) представляется возможным. Это обусловлено допустимостью наличия в некой отрасли права таких положений, которые, по сути, хотя и принадлежат к отрасли иной, но необходимы для расположения вне своей сферы с целью полноты, последовательности и (или) простоты регламентации, познания и (или) изучения той отрасли права, в которой соответствующие поведенческие правила фактически расположены» ${ }^{16}$.

В отношении военного права сторонником третьей позиции является В.М. Корякин, сделавший вывод о том, что военное право, можно разделить на две большие части. Существует некая часть собственно военного права, которая регулирует отношения в военной организации государства. Одновременно существует и другая его часть, которую составляют нормы и институты других отраслей права, имеющие так называемую «двойную прописку». В военном праве в силу специфики его предмета доля правовых норм, которые имеют как бы два адреса «прописки», весьма значительна» ${ }^{17}$.

Действительно, как относительно самостоятельная правовая отрасль, военное право обладает

советского социалистического права. — «Советское государство и право», 1958, № 11, с.10-11).

${ }^{16}$ Д.М. Азми Историко-теоретический и методологический анализ структуры права. Автореф. дисс. ... докт. юр. наук. М. 2011г. С. 40.

${ }^{17}$ Корякин В.М. Введение в теорию военного права (монография) / Военное право: сборник документов: Российский военноправовой сборник № 9: Военное право в XXI веке. Серия «Право в Вооруженных Силах - консультант». «За права военнослужащих», 2007. URL: http://voenprav.ru/doc-3922-1.htm (дата обращения: 22.01.2014). 
DOI: $10.7256 / 1811-9018.2014 .3 .11104$

При цитировании этой статьи сноска на доі обязательна

\section{Право и политика $3(171) \cdot 2014$}

«уникальностью», которая выражается как в предмете правового регулирования, основу которого составляют воинские правоотношения, так и во властно-обязывающем характере метода данной отрасли. Участниками воинских правоотношений являются военнослужащие, т.е. лица, исполняющие обязанности, связанные с прохождением военной службы, которая призвана решать задачи в сфере безопасности и обороны государства, и в связи с этим обладающие специальным правовым статусом. Субъектами отношений, регулируемых военным правом, являются также военные организации, правовое положение которых определено Федеральным законом «Об обороне» ${ }^{18}$ (далее по тексту - Закон «Об обороне), но при этом особенности их деятельности определены Гражданским кодексом России ${ }^{19}$ и рядом других федеральных нормативных правовых актов. Метод военного права характеризуется властно-обязывающим характером, «обусловленным особенностями предмета данной отрасли права, а также непосредственной связью с военной политикой государства. Метод правового регулирования военного права преимущественно императивный и направлен на обеспечение стабильности в военной организации государства и предсказуемости происходящих в ней процессов» ${ }^{20}$.

В пользу комплексности военного права свидетельствует наличие так называемых «приграничных зон», то есть регулирование одних и тех же вопросов различными отраслями права. Так, например, правовое регулирование жилищных отношений военнослужащих осуществляется как Федеральным законом «О статусе военнослужащих» ${ }^{21}$, так и Жилищным кодексом ${ }^{22}$. Военное право тесно взаимодействует с уголовным и уголовно-исполнительным правом в вопросах уголовной ответственности военнослужащих и исполнения в отношении их уголовных наказаний. Воинские отношения регулируются также рядом других отраслей, составляющих публичное право.

\footnotetext{
${ }^{18}$ Федеральный закон от 27.05.1998 № 76-Ф3 «О статусе военнослужащих» // Собрание законодательства Российской Федерации, № 22, 01.06.1998, ст. 2331.

19 Гражданский кодекс Российской Федерации (часть первая) от 30.11.1994 № 51-Ф3 // Собрание законодательства Российской Федерации, 05.12.1994, № 32, ст. 3301.

${ }^{20}$ Корякин В.М. Введение в теорию военного права (монография).

${ }^{21}$ Федеральный закон от 27.05.1998 № 76-Ф3 «О статусе военнослужащих» // Собрание законодательства Российской Федерации, № 22, 01.06.1998, ст. 2331.

22 Жилищный кодекс Российской Федерации от 29 декабря 2004 г. N 188-Ф3. // Собр. законодательства РФ. 2005 г. № 1 (часть I), ст. 14
}

Таким образом, часто можно наблюдать отсутствие четкого разграничения военного права, предусматривающего ясный и исчерпывающий «раздел» территории, от других отраслей. Такое положение объясняется тем, что регулирование широкого круга отношений в области обеспечения военной безопасности силами и средствами одной отрасли права в настоящее время практически невозможно в силу их разнородного характера.

Ряд ученых правоведов рассматривают правовой институт как группу норм, объективно сложившихся внутри отрасли права. Он является необходимой первичной общностью юридических норм. Степень тяготения норм друг к другу не планируется заранее, новые правовые институты не выделяются искусственно, а складываются объективно, юридические нормы составляют гармоничные группы, подчиняясь внутренним закономерностям, которые в то же время являются закономерностями, объединяющими конкретные общественные отношения, которые призваны урегулировать правовые нормы ${ }^{23}$.

Наряду с институтами, действующими в пределах отрасли права (внутриотраслевые), существуют также институты, включающие в себя нормы нескольких отраслей права (межотраслевые). В научной и учебной литературе их называют также смешанными институтами, или комплексными институтами. В качестве примера можно назвать институт государственного оборонного заказа.

Межотраслевые «пограничные» институты возникают как следствие тесного взаимодействия на определенном участке предметов регулирования смежных однородных отраслей права. В результате на границе указанных отраслей образуются зоны, регламентирующие единое по существу общественное отношение, обладающее, однако, определенными оттенками, модификациями, обусловленными спецификой той или иной отрасли.

В пользу существования межотраслевого правового регулирования отношений в области обеспечения военной безопасности свидетельствует наличие норм российского законодательства, которые тем или иным образом имеют отношение к гражданско-правовой деятельности субъектов военного права. К ним относится, в частности, Закон «Об обороне», который в ст. 1 устанавливает, что «имущество Вооруженных Сил Российской Федерации,

${ }^{23}$ См.: Керимов Д.А. Философские проблемы права. М., 1972.C. 300; Алексеев С.С. Структура советского права. М., 1975. С. 31; Иоффе О.С. Структурные подразделения системы права (на материалах гражданского права) // Ученые записки ВНИИС3. Вып. 14.М. , 1968. С. 54 
других войск, воинских формирований и органов является федеральной собственностью и находится у них на правах хозяйственного ведения или оперативного управления». Федеральным Законом от 9 апреля 2009 г. № 57-Ф3 «О внесении изменений в Федеральный закон «Об обороне» Закон «Об обороне» ${ }^{24}$ дополнен положением, согласно которому управления объединений, управления соединений и воинские части Вооруженных Сил Российской Федерации действуют в качестве юридических лиц в форме федерального казенного учреждения. При этом решение о создании в качестве юридического лица управления сформированного объединения, управления сформированного соединения или сформированной воинской части Вооруженных Сил Российской Федерации, а также о реорганизации или ликвидации указанного юридического лица принимается министром обороны Российской Федерации. Управления объединений, управления соединений и воинские части Вооруженных Сил Российской Федерации в качестве юридических лиц действуют на основании общих положений, утверждаемых министром обороны Российской Федерации.

Вызывает интерес рассмотрение таких аспектов межотраслевого (военно-правового и гражданскоправового) регулирования, как вопросы организации и порядка перевозок, поставки продукции, вооружения и военной техники для нужд обороны, договорной работы в военных организациях, правового режима имущества военных организаций, ответственности военных организаций и военнослужащих по гражданско-правовым обязательствам, защиты прав, чести, достоинства и деловой репутации военнослужащих, деятельности субъектов различных направлений военного сотрудничества, применения гражданского законодательства в сфере военного управления и др.

Следует признать, что военнослужащий, являясь членом общества, на котором лежит первоочередная обязанность по вооруженной защите Отечества, представляет собой особый субъект правоотношений. Однако в силу своего специального статуса осуществление и защита ряда гражданских прав военнослужащего подлежит специальному правовому регулированию. Так, Федеральный закон от 27 мая 1998 года № 76-Ф3 «О статусе военнослужащих» ${ }^{25}$ содержит положения

\footnotetext{
${ }^{24}$ Федеральный Закон Российской Федерации от 9 апреля 2009 г. N 57-Ф3 «О внесении изменений в Федеральный закон «Об обороне» закон «Об обороне» Собрание законодательства Российской Федерации № 15 от 13 апреля 2009 г.

${ }^{25}$ Федеральный закон от 27.05.1998 № 76-Ф3 «О статусе военнослужащих» // Собрание законодательства Российской Федерации, № 22, 01.06.1998, ст. 2331.
}

о правах военнослужащих в области жилищных отношений, охраны здоровья, образования, свободы передвижения и выбора места жительства.

Согласно п. 2 ст. 1 Федерального закона «О статусе военнослужащих» военнослужащие обладают правами и свободами человека и гражданина с некоторыми ограничениями, установленными законодательством. Следует напомнить, что действовавшим до 1993 года Законом СССР «О всеобщей воинской обязанности» ${ }^{26}$ устанавливалось, что военнослужащие и призванные на военные сборы военнообязанные пользуются всей полнотой социально-экономических, политических и личных прав и свобод и исполняют все обязанности граждан, предусмотренные Конституцией СССР. Из указанного законодательного положения некоторые советские военные ученые-юристы выводили такой принцип военного права, как политическое и гражданское полноправие военнослужащих как граждан государства ${ }^{27}$.

Наличие указанных ограничений в отношении военнослужащих России не может расцениваться как умаление конституционных прав военнослужащих, так как возможность ограничения законом прав граждан предусмотрена Конституцией Российской Федерации ${ }^{28}$ : «Права и свободы человека и гражданина могут быть ограничены федеральным законом только в той мере, в какой это необходимо в целях защиты основ конституционного строя, нравственности, здоровья, прав и законных интересов других лиц, обеспечения обороны страны и безопасности государства». Иными словами, права гражданина могут быть ограничены «в общественно значимых целях, ради защиты которых допускается ограничение прав человека $»^{29}$. Кроме того, как говорилось выше, в связи с особым характером обязанностей, возложенных на военнослужащих, и ограничением их некоторых общегражданских прав им предоставляются (во всяком случае, должны предоставляться) достойные социальные гарантии и компенсации.

\footnotetext{
${ }^{26}$ Консультант. URL : http://base.consultant.ru/cons/cgi/online. cgi?req=doc;base=ESU;n=5955 (дата обращения: 22.01.2014).

${ }^{27}$ См., например: Романов П.И. Общие права и обязанности военнослужащих Вооруженных Сил СССР. М., 1965. С. 25; Серегин В.П. Военное право: Учебник. М., 1988. С. 242; Военное право: Учебное пособие / Под общ. ред. А.Г. Горного. С. 36.

${ }^{28}$ Конституция Российской Федерации. Принята всенародным голосованием 12.12.1993. Российская газета, № 7, 21.01.2009.

29 Зорькин В.Д. Угрозы международной и национальной безопасности и ограничения прав человека в практике конституционного правосудия // Конституционное правосудие. Вестник Конференции органов конституционного контроля стран молодой демократии. Ереван, 2005. Вып. 3(29). С. 50.
} 


\section{Право и политика $3(171) \cdot 2014$}

Назначение законодательно установленных запретов и ограничений некоторых общегражданских прав военнослужащих состоит в том, чтобы:

- обеспечить эффективную служебную деятельность военнослужащих;

- установить препятствия возможным злоупотреблениям должностными полномочиями со стороны военнослужащих;

- создать условия для независимости служебной деятельности военнослужащих от какого-либо влияния, не связанного с военной службой ${ }^{30}$.

По смыслу ст. 37 (ч. 1) и ст. 59 Конституции Российской Федерации ${ }^{31}$ во взаимосвязи с ее ст. 32 (ч. 4), ст. 71 (п. «м»), ст. 72 (п. «б» ч. 1) и ст. 114 (п. п. «Д», «е»), военная служба, посредством прохождения которой граждане реализуют свое право на труд, представляет собой особый вид государственной службы, непосредственно связанной с обеспечением обороны страны и безопасности государства, общественного порядка, законности, прав и свобод граждан и, следовательно, осуществляемой в публичных интересах. Лица, несущие такого рода службу, выполняют конституционно значимые функции, чем обусловливается их правовой статус ${ }^{32}$.

С другой стороны, заключив контракт о прохождении военной службы, военнослужащий становится равноправным участником правоотношений с государством, поскольку «...наряду с единым правообразующим центром (государством) существует необозримое множество других «центров» - самостоятельных субъектов права, действующих на началах диспозитивности, правовой самостоятельности, юридического равенства между всеми субъектами, включая государственную власть» ${ }^{33}$. Таким образом, военнослужащий может вступать в гражданско-правовые отношения, где действуют не императивные, а диспозитивные принципы.

Понятие «военная организация» в военной правовой науке используется в двух смыслах. В широком смысле содержание данного понятия раскрыто в Военной доктрине Российской Федерации ${ }^{34}$, а структурный состав

\footnotetext{
${ }^{30}$ См.: Кудашкин А.B. Военная служба в Российской Федерации: теория и практика правового регулирования. Монография. URL: http://voenprav.ru/doc-2478-1.htm (дата обращения: 13.02.2014).

31 Конституция Российской Федерации. Принята всенародным голосованием 12.12.1993. Российская газета, № 7, 21.01.2009.

${ }^{32}$ Корякин В.M. Указ. соч. С. 53

${ }^{33}$ Алексеев С.С. Избранное. М., 2003. С. 105.

${ }^{34}$ См.: п.6 подп. «к». Указ Президента Российской Федерации от 05.02.2010 № 146 «О Военной доктрине Российской Федерации » // Собрание законодательства Российской Федерации, 15.02.2010, № 7 , ст. 724 .
}

«военной организации» - в ст. 1 Федерального закона Российской Федерации «Об обороне» ${ }^{35}$. Согласно указанным документам военная организация государства - совокупность органов государственного и военного управления, Вооруженных Сил Российской Федерации, других войск, воинских формирований и органов, составляющих ее основу и осуществляющих свою деятельность военными методами, а также части производственного и научного комплексов страны, совместная деятельность которых направлена на подготовку к вооруженной защите и вооруженную защиту Российской Федерации. Несомненно, одним из ключевых элементов военной организации государства являются собственно сами военные организации (учреждения и предприятия), составляющие ее форму, внешнюю структуру. В узком смысле под военными организациями понимаются организации, входящие в состав Вооруженных Сил Российской Федерации, иных войск, воинских формирований и органов. О двух смыслах содержания понятия «военная организация» говорит и Л. Н. Сморчкова, которая указывает, что в широком смысле под военной организацией подразумевается государственная структура или совокупность нескольких структур, функции которых связаны с защитой государства военными средствами. В узком смысле - определенным образом обособленное подразделение такой военной государственной структуры ${ }^{36}$. Таким образом, можем констатировать, что понятие «военная организация» рассматривается как в широком смысле - в качестве государственной структуры (военной организации государства), составляющей основу обороны государства, так и в узком смысле как юридическое лицо, организационно входящее в военную организацию государства.

В настоящее время, когда в имущественные отношения вовлекается все большее количество субъектов, вопросы правового положения военных организаций как полноправных участников не только военно-административных, но и гражданско-правовых отношений,

\footnotetext{
35 Федеральный закон от 31.05.1996 № 61-Ф3 «Об обороне» // Собрание законодательства Российской Федерации , 03.06.1996, № 23 , ст. 2750.

${ }^{36}$ Сморчкова Л.Н. Правовой режим имущества, полученного организациями Пограничной службы Российской Федерации за счет внебюджетных источников: дис... канд. юрид. наук. М., 2002. С. 36. Я.А. Гейвандов также говорит о различном содержании термина «военная организация» в нормативных актах. См.: Гейвандов Я. $A$. Организации, обеспечивающие вооруженную защиту Российской Федерации (некоторые аспекты соотношения публично-правового содержания и организационно-правовой формы) // Государство и право. 1999. № 2. С. 5-6.
} 
актуальны и востребованы в деятельности Вооруженных Сил Российской Федерации и других войск.

Обязательным условием участия военной организации в гражданских правоотношениях является наличие статуса юридического лица. Любое научно-правовое исследование должно исходить из того, что военная организация - юридическое лицо, самостоятельный участник правоотношений, в противном случае исследования различных правовых аспектов военных организаций будет лишено предметной направленности.

Конструкция юридического лица является гражданско-правовым средством, определяющим степень участия организаций в гражданском обороте и обусловливающим применение в их деятельности тех или иных гражданско-правовых норм. По мнению Б.В. Пугинского, юридическое лицо - это предусмотренный законодательством признак организации, наделение которым в установленном порядке предоставляет ей возможность самостоятельного участия в гражданском обороте ${ }^{37}$.

На сегодняшний день военные организации могут существовать в основном в следующих организационно-правовых формах: учреждение и предприятие. Федеральный закон № 83-Ф338 конкретизировал типы учреждений. Так, учреждения могут быть трех типов: казенными, бюджетными и автономными. При этом данный закон приводит исчерпывающий перечень организаций, которые должны быть отнесены к казенным учреждениям. В соответствии с законодательством Российской Федерации ${ }^{39}$ целью создания и деятельности как казенного, так и бюджетного и автономного учреждения является обеспечение реализации предусмотренных законодательством Российской Федерации полномочий органов государственной власти в сферах науки, образования, здравоохранения, культуры, социальной защиты, занятости населения, физической культуры и спорта, а также в иных сферах. Так как перечень сфер полномочий органов государственной власти, обеспечение которых осуществляется посредством деятельности

\footnotetext{
${ }^{37}$ См.: Пугинский Б.И. Основные проблемы гражданско-правовых средств: Дисс. ... докт. юр. наук. М., 1985. С. 303.

${ }^{38}$ См.: ст. 31.Федеральный закон от 08.05.2010 № 83-Ф3 «О внесении изменений в отдельные законодательные акты Российской Федерации в связи с совершенствованием правового положения государственных (муниципальных) учреждений» // Собрание законодательства Российской Федерации, 10.05.2010, № 19, ст. 2291.

${ }^{39}$ См.: Бюджетный кодекс Российской Федерации от 31.07.1998 № 145-Ф3 // Собрание законодательства Российской Федерации, 03.08.1998, № 31, ст. 3823; Федеральный закон от 03.11.2006 № 174Ф3 «Об автономных учреждениях» // Собрание законодательства Российской Федерации, 06.11.2006, № 45, ст. 4626.
}

учреждений, не является исчерпывающим, закономерно причисление к ним такой сферы, как оборона и военная безопасность государства.

Бюджетным кодексом Российской Федерации ${ }^{40}$ определены виды деятельности военных организаций. Таковыми являются выполнение работ, оказания услуг (для казенных и автономных учреждений), а также исполнение государственных функций (данный вид деятельности осуществляют казенные учреждения, наряду с выполнением работ и оказанием услуг) в целях обеспечения реализации предусмотренных законодательством Российской Федерации полномочий органов государственной власти в сфере обороны и обеспечения безопасности государства.

Типовое общее положение о федеральном казенном учреждении «Управление объединения (управление соединения, воинская часть) Вооруженных Сил Российской Федерации» (далее - Типовое положение $)^{41}$ конкретизирует цель деятельности учреждения, которая заключается в обеспечении поддержания постоянной боевой и мобилизационной готовности объединения (соединения, воинской части) и подразделений, не входящих в его состав, но состоящих при нем на обеспечении, и осуществлении управленческих, обеспечивающих и иных функций в соответствии с законодательством Российской Федерации.

Видами деятельности военных организаций согласно Типовому положению являются: обеспечение организации боевого дежурства, боевой и мобилизационной подготовки, проведения учений, оперативных тренировок и иных мероприятий в соответствии с утвержденными планами и в порядке, установленном в Министерстве обороны Российской Федерации; обеспечение функционирования закрепленных и предоставленных в пользование объектов материально-технической базы; организацию и осуществление всех видов боевого, технического, тылового, финансового, медицинского и моральнопсихологического обеспечения; ведение договорной и договорно-претензионной работы; иные виды дея-

\footnotetext{
${ }^{40}$ См.: Бюджетный кодекс Российской Федерации от 31.07.1998 № 145-Ф3 // Собрание законодательства Российской Федерации, 03.08.1998, № 31, ст. 3823 .

${ }^{41}$ Приказ Министра обороны Российской Федерации от 29.07.2011 № 1290 «Об утверждении Типового общего положения о федеральном казенного учреждении «Управление объединения (управление соединения, воинская часть) ВС РФ» и Типового положения о филиале «Войсковая часть 00000» федерального казенного учреждения «Управление объединения (управление соединения, воинская часть) ВС РФ». Документ опубликован не был. Правовая система «Consultant plus».
} 
DOI: $10.7256 / 1811-9018.2014 .3 .11104$

При цитировании этой статьи сноска на доі обязательна

\section{Право и политика $3(171) \cdot 2014$}

тельности в соответствии со своим функциональным предназначением ${ }^{42}$.

Военная организация может в соответствии с законодательством Российской Федерации выступать государственным заказчиком при размещении заказов на поставки товаров, выполнение работ, оказание услуг для государственных нужд ${ }^{43}$.

Согласно ч. 2 п. 3 ст. 50 Гражданского кодекса Российской Федерации любое учреждение (в том числе военное) как некоммерческая организация имеет право осуществлять предпринимательскую деятельность, поскольку это служит достижению целей, ради которых оно создано.

Согласно ч. 2 ст. 298 Гражданского кодекса Российской Федерации учреждение имеет возможность осуществлять приносящую доходы деятельность, если такое право предоставлено ему учредительными документами ${ }^{44}$.

На основании анализа массива нормативных правовых актов, составляющих военное законодательство России, можем заключить, что предметными областями деятельности военных организаций, включающими в себя гражданско-правовые аспекты являются следующие сферы:

- деятельность, связанная с оперативным управлением имуществом военных организаций;

- деятельность, связанная с реализацией высвобождаемого военного имущества.

- деятельность, связанная с подготовкой и заключением гражданско-правовых договоров, а также исполнением договорных обязательств.

- деятельность, связанная с ответственностью военных организаций за нарушения договорных обязательств.

- деятельность, связанная с возмещением вреда.

Общие гражданско-правовые аспекты деятельности военных организациях в перечисленных выше

\footnotetext{
${ }^{42}$ См.: п. 16 Типового общего положения о федеральном казенном учреждении «Управление объединения (управление соединения, воинская часть) ВС РФ», введенного в действие Приказом Министра обороны Российской Федерации от 29.07.2011 № 935. Правовая система «Consultant plus».

${ }^{43}$ См.: Приказ Министра обороны Российской Федерации от 29.07.2011 № 1290 «Об утверждении Типового общего положения о федеральном казенного учреждении «Управление объединения (управление соединения, воинская часть) ВС РФ» и Типового положения о филиале «Войсковая часть 00000» федерального казенного учреждения «Управление объединения (управление соединения, воинская часть) ВС РФ». Документ опубликован не был. Правовая система «Consultant plus».

${ }^{44}$ См.: Сморчкова Л.Н. Проблемы правового регулирования предпринимательской и иной приносящей доходы деятельности военных учреждений. С. 155.
}

сферах регулируются нормами гражданского права. Отдельные же вопросы, возникающие в процессе такой деятельности, имеющие значение для обеспечения обороны и безопасности государства, детальным образом урегулированы нормами военного законодательства. Например, приказом Министра обороны Российской Федерации от 24 декабря 2010 года № 1912 «О видах особо ценного движимого имущества федеральных бюджетных и автономных учреждений Минобороны России» ${ }^{45}$ к особо ценному движимому имуществу относится движимое имущество независимо от его балансовой стоимости, необходимое для осуществления основной деятельности федеральных бюджетных и автономных учреждений Минобороны России, а также имущество, связанное с выполнением государственного задания. К этой же категории имущества относится движимое имущество указанных учреждений, балансовая стоимость которых превышает 500 тысяч рублей, а также движимое имущество, отчуждение которого осуществляется в специальном порядке, установленном законом и иными нормативными правовыми актами Минобороны России. В данном случае, можно говорить о конкретизации нормами военного законодательства положений гражданского законодательства.

Особенностью военных организаций как юридических лиц (государственных учреждений) является то, что они обладают двойственным свойством. С одной стороны, это особые субъекты правоотношений, деятельность которых регулируется специальным военным законодательством. Действуя от имени государства, они императивными методами регулируют отношения с другими субъектами правоотношений. В то же время в некоторых случаях они как равноправные участники гражданско-правовых отношений действуют в рамках общего гражданского права. Эти отношения относятся к категории горизонтальных диспозитивных отношений. Для обеспечения участия военных организаций в гражданском товарообороте необходимо принятие определенных правовых норм на стыке военного и гражданского права, учитывающих специфику регулирования данных имущественных отношений.

Определяя контуры обозначенной проблемы, необходимо выработать направления ее решения, которые могут вытекать из нижеприведенных тезисов:

\footnotetext{
${ }^{45}$ Приказ Министра обороны Российской Федерации от 24.12. 2010 № 1912 «О видах особо ценного движимого имущества федеральных бюджетных и автономных учреждений Министерства обороны Российской Федерации». Документ опубликован не был. Правовая система «Consultant Plus». URL: http://www.consultant.ru/document/ cons_doc_LAW_131334/(дата обращения 13.02.2014).
} 
1. Проводимые реформы последних двух десятилетий в области обеспечения военной безопасности были предопределены различными факторами: сменой военно-стратегических и военно-политических устремлений России (отличных от бывшего СССР), построением военного ведомства по новому типу комплектования, приданием «нового облика» Вооруженным Силам России с использованием инструментов как правового, так и экономического характера. Значительная роль в данном процессе отведена военному праву. На сегодняшний день в правовой науке не существует единого мнения о месте военного права в правовой системе России, и, следовательно, не выработаны единые принципы построения и функционирования военного права как самостоятельного элемента в отечественной системе права.

2. Наличие в системе источников военного права норм, заимствованных из других правовых отраслей, и факт регулирования соответствующими нормами отношений, составляющих предмет военного права, позволяет сделать вывод о том, что военное право включает в себя институты межотраслевого правового регулирования. Такими институтами могут являться: институт военно-конституционного права, военноуголовного права, институт военной администрации, институт, включающий в себя гражданско-правую составляющую, и другие.

Выявление и систематизация отношений в области обеспечения военной безопасности, упорядочение которых осуществляется нормами, как военного, так и гражданского права, также установлении возможности образования соответствующего межотраслевого правового института представляется нам одной из проблем, решение которой позволит более эффективно осуществлять правовое регулирования правоотношений в области обеспечения военной безопасности государства с учетом современного уровня развития российского общества.

3. Оценивая существующую правовую систему России можно сказать, что она поражает своей обширной законодательной базой. Наряду с основополагающими законодательными документами и институтами в законодательстве плохо различимы иные отнюдь не менее важные правовые акты, регулирующие отдельные вопросы правовой действительности, упорядочивание которых подпадает под действие норм нескольких отраслей права, зачастую не близких по предмету и (или) методу правового регулирования. По нашему мнению, деятельность по выявлению, систематизации и, возможно, консолидации в едином правовом документе нормативных актов и отдельных норм, регулирующих отношения, непосредственно связанные с обеспечением военной безопасности государства, но принадлежащие иным отраслям права, чрезвычайно важна для повышения эффективности деятельности военной организации государства.

4. Субъекты военного права, предназначенные для выполнения задач по обеспечению обороноспособности государства военными методами, вынуждены существовать в условиях мирного времени, в том числе активно взаимодействовать с субъектами гражданского права, прежде всего, по вопросам имущественного оборота.

Так, военные организации вступают в имущественные отношения, заключая договоры поставки, перевозки, подряда, оказания услуг и другие. В то же время каждый военнослужащий согласно Конституции Российской Федерации вправе иметь имущество в частной собственности, владеть, пользоваться и распоряжаться им по собственному усмотрению как единолично, так и совместно с другими лицами. Также военнослужащие вступают в имущественные отношения по поводу авторства на изобретения, произведения науки, литературы и искусства и личные неимущественные отношения, связанные с охраной жизни, здоровья, достоинства личности, чести и доброго имени, личной неприкосновенностью и др.

Однако в существующей системе российского права действует фрагментарный и бессистемный механизм правового регулирования особенностей участия военных организаций и военнослужащих в гражданских правоотношениях, что в немалой степени обусловлено отсутствием в современной правовой науке комплексных и непротиворечивых исследований и концептуальных разработок по проблеме гражданскоправового регулирования перечисленных субъектов в имущественном обороте.

5.Тридцатилетняя история существования научной специальности 20.02.03. «Военное право. Военные проблемы международного права» свидетельствует о ее востребованности для юридической, военной науки и практики, для целей законодательной, нормотворческой, практической и учебно-методической деятельности в России. Вместе с тем за последние годы наметилась объективная тенденция к расширению сферы предмета исследований в области военного права, детерминируемая изменяющимися социальноэкономическими и политико-правовыми реалиями, реформированием военной организации государства, включением в гражданский оборот все большего ко- 


\section{Право и политика $3(171) \cdot 2014$}

личества участников. В этой связи представляется назревшим вопрос расширения научной специальности 20.02 .03 за счет расширения и конкретизации раздела «Военные аспекты гражданского права». Такой шаг открыл бы новые актуальные направления научных исследований в области межотраслевого регулирования норм военного права и гражданского права в соответствии с современными угрозами и вызовами безопасности, с которыми приходится сталкиваться военной организации государства, а также уровнем развития общественных и экономических отношений на современном этапе.

\section{Библиография:}

1. Агарков М.М. Предмет и система советского гражданского права // Советское государство и право. 1940. № 8-9.

2. Азми Д.М. Историко-теоретический и методологический анализ структуры права. Автореф. дисс. ...доктр.юр.наук. М., 2011.

3. Алексеев С.С. Общие теоретические проблемы системы советского права. М., 1961.

4. Алексеев С.С. Структура советского права. М., 1975.

5. Ахметшин Х.М. Военно-уголовное законодательство в системе военного права // Российский военно-правовой сборник. 2004. № 1.

6. Ахметшин Х.М. Военно-уголовное законодательство Российской Федерации // Военно-уголовное законодательство Российской Федерации: Научнопрактический комментарий / Под ред. Н.А. Петухова. М., 2004.

7. Зорькин В.Д. Угрозы международной и национальной безопасности и ограничения прав человека в практике конституционного правосудия // Конституционное правосудие. Вестник конференции органов конституционного контроля стран молодой демократии. Ереван., 2005. Вып. 3 (29).

8. Иоффе О.С. Структурные подразделения системы права (на материалах граж-данского права) // Ученые записки ВНИИС3. Вып. 14., М., 1968.

9. Керимов Д.А. Философские проблемы права. М., 1972.

10. Корякин В.М. Введение в теорию военного права (монография) // Российский военно-правовой сборник № 9: Военное право в XXI веке. Серия «Право в Вооруженных Силах - консультант» // За права военнослужащих. 2007.
11. Красавчиков О.А. Советская наука гражданского права (понятие, предмет, состав и система). Учен. Труды Свердловского юрид. ин-та. Свердловск. Т. 6.

12. Кудашкин А.В. Военная служба в Российской Федерации: теория и практика правового регулирования. Монография. URL: http://voenprav.ru/ doc-2478-1.htm.

13. Орлов Г.В. О структуре советского военного законодательства // 40 лет военно-юридическому образованию в СССР. Сборник статей. М., 1977.

14. Орлов Г.В. Предмет регулирования комплексной отрасли советского законодательства // Сборник статей Военного Краснознаменного института. М., 1985. № 21 .

15. Павлов И.В. О системе советского социалистического права // Советское государство и право. 1958. № 11.

16. Пугинский Б.И. Основные проблемы гражданскоправовых средств: Дисс. ... докт. юр. наук. М., 1985.

17. Романов П.И. Военное право как отрасль советского законодательства, учебная и научная дисциплина // Вопросы теории военного законодательства и практики его применения. М., 1974.

18. Романов П.И. Общие права и обязанности военнослужащих Вооруженных Сил СССР. М., 1965.

19. Сморчкова Л.Н. Проблемы правового регулирования предпринимательской и иной приносящей доходы деятельности военных учреждений // Материалы межведомственной научно-практической конференции. МПИ ФПС Российской Федерации. 2003.

20. Толкаченко А.А. Современное состояние военноюридической (военно-правовой) науки и ее роль в укреплении безопасности России // Право и безопас-ность. 2007. № 3-4.

21. А.В. Фомин. Нормативно-правовые аспекты военно-технического сотрудничества России с государствами-членами ОДКБ. // Политика и Общество. - 2013. - № 2. - C. 183-188. DOI: .10.7256/1812 8696.2013.02.8

22. А. Р. Хагуш. Роль международных двусторонних договоров в регулировании военно-технического сотрудничества России с иностранными государствами. // Международное право и международные организации / International Law and International Organizations.-2012.-№ 2.-C. 124-132.

23. А. А. Лукашев. Подотраслевая природа финансовоправовых норм, регулирующих бюджетные отношения. // Финансовое право и управление. - 2013. № 2. - С. 77-101. DOI: .10.7256/2310-0508.2013.2.9863 
24. К Канунникова Н.Г.. Теоретические аспекты системы административного права. // Административное и муниципальное право. - 2012. - № 10. - С. 5-11.

25. Дырда С.Г.. К вопросу о предмете муниципального права. // Административное и муниципальное право. - 2012. - № 7. - С. 9-12.

26. Лапина Е.Б.. Государственные закупки государственных услуг. // Административное и муниципальное право. - 2013. - № 9. - С. 901-909. DOI: .10.7256/1999-2807.2013.9.948

27. Костенников М.В. К вопросу о некоторых актуальных проблемах административного права // NB: Административное право и практика администрирования. -2013. - 4. - C. 71 - 95. DOI: 10.7256/23069945.2013.4.8840. URL: http://www.e-notabene.ru/al/ article_8840.html

28. Дырда С.Г. К вопросу о предмете муниципального права // Административное и муниципальное право. - 2012. - 7. - С. 9 - 12.

29. Сергунин А.А. Концепт «Военная безопасность» и эволюция военно-политического мышле-ния постсоветской России // NB: Национальная безопасность. - 2012. - 2. - С. 119 - 140. URL: http:// www.e-notabene.ru/nb/article_183.html

\section{References (transliteration):}

1. Agarkov M.M. Predmet i sistema sovetskogo grazhdanskogo prava // Sovetskoe gosudarstvo i pravo. 1940. № 8-9.

2. Azmi D.M. Istoriko-teoreticheskii i metodologicheskii analiz struktury prava. Avtoref. diss. ...doktr.yur.nauk. M., 2011.

3. Alekseev S.S. Obshchie teoreticheskie problemy sistemy sovetskogo prava. M., 1961.

4. Alekseev S.S. Struktura sovetskogo prava. M., 1975.

5. Akhmetshin Kh.M. Voenno-ugolovnoe zakonodatel'stvo v sisteme voennogo prava // Rossiiskii voenno-pravovoi sbornik. 2004. № 1.

6. Akhmetshin Kh.M. Voenno-ugolovnoe zakonodatel'stvo Rossiiskoi Federatsii// Voenno-ugolovnoe zakonodatel'stvo Rossiiskoi Federatsii: Nauchno-prakticheskii kommentarii / Pod red. N.A. Petukhova. M., 2004.

7. Zor'kin V.D. Ugrozy mezhdunarodnoi i natsional'noi bezopasnosti i ograni-cheniya prav cheloveka v praktike konstitutsionnogo pravosudiya // Konstitutsion-noe pravosudie. Vestnik konferentsii organov konstitutsionnogo kontrolya stran molodoi demokratii. Erevan., 2005. Vyp. 3 (29).
8. Ioffe O.S. Strukturnye podrazdeleniya sistemy prava (na materialakh grazh-danskogo prava) // Uchenye zapiski VNIISZ. Vyp. 14., M., 1968.

9. Kerimov D.A. Filosofskie problemy prava. M., 1972.

10. Koryakin V.M. Vvedenie $\mathrm{v}$ teoriyu voennogo prava (monografiya) // Rossiiskii voenno-pravovoi sbornik № 9: Voennoe pravo v XXI veke. Seriya «Pravo v Vo-oruzhennykh Silakh - konsul'tant» // Za prava voennosluzhashchikh. 2007.

11. Krasavchikov O.A. Sovetskaya nauka grazhdanskogo prava (ponyatie, predmet, so-stav i sistema). Uchen. Trudy Sverdlovskogo yurid. in-ta. Sverdlovsk. T. 6.

12. Kudashkin A.V. Voennaya sluzhba v Rossiiskoi Federatsii: teoriya i praktika pravovogo regulirovaniya. Monografiya. URL: http://voenprav.ru/doc-2478-1.htm.

13. Orlov G.V. O strukture sovetskogo voennogo zakonodatel'stva // 40 let voen-no-yuridicheskomu obrazovaniyu v SSSR. Sbornik statei. M., 1977.

14. Orlov G.V. Predmet regulirovaniya kompleksnoi otrasli sovetskogo zakono-datel'stva // Sbornik statei Voennogo Krasnoznamennogo instituta. M., 1985. № 21.

15. Pavlov I.V. O sisteme sovetskogo sotsialisticheskogo prava // Sovetskoe gos-udarstvo i pravo. 1958. № 11.

16. Puginskii B.I. Osnovnye problemy grazhdanskopravovykh sredstv: Diss. ... dokt. yur. nauk. M., 1985.

17. Romanov P.I. Voennoe pravo kak otrasl' sovetskogo zakonodatel'stva, ucheb-naya i nauchnaya distsiplina // Voprosy teorii voennogo zakonodatel'stva i prak-tiki ego primeneniya. M., 1974.

18. Romanov P.I. Obshchie prava i obyazannosti voennosluzhashchikh Vooruzhennykh Sil SSSR. M., 1965.

19. Smorchkova L.N. Problemy pravovogo regulirovaniya predprinimatel'skoi i inoi prinosyashchei dokhody deyatel'nosti voennykh uchrezhdenii // Materialy mezh-vedomstvennoi nauchno-prakticheskoi konferentsii. MPI FPS Rossiiskoi Fe-deratsii. 2003.

20. Tolkachenko A.A. Sovremennoe sostoyanie voennoyuridicheskoi (voenno-pravovoi) nauki i ee rol' v ukreplenii bezopasnosti Rossii // Pravo i bezopas-nost'. 2007. № 3-4.

21. A.V. Fomin. Normativno-pravovye aspekty voennotekhnicheskogo sotrudnichestva Rossii s gosudarstvami-chlenami ODKB. // Politika i Obshchestvo. - 2013. - № 2. - C. 183-188. DOI: .10.7256/1812 - 8696.2013.02.8

22. A. R. Khagush. Rol' mezhdunarodnykh dvustoronnikh dogovorov v regulirovanii voenno-tekhnicheskogo sotrudnichestva Rossii s inostrannymi gosudarstvami. // Mezhdunarodnoe pravo i mezhdunarodnye organizatsii / International Law and International Organizations. - 2012. - № 2. - C. 124-132. 
DOI: $10.7256 / 1811-9018.2014 .3 .11104$

При цитировании этой статьи сноска на доі обязательна

\section{Право и политика $3(171) \cdot 2014$}

23. A. A. Lukashev. Podotraslevaya priroda finansovopravovykh norm, reguliruyushchikh byudzhetnye otnosheniya. // Finansovoe pravo i upravlenie.-2013.-№ 2.-C. 77-101. DOI: .10.7256/2310-0508.2013.2.9863

24. Kanunnikova N.G.. Teoreticheskie aspekty sistemy administrativnogo prava. // Administrativnoe i munitsipal'noe pravo.-2012.-№ 10.-C. 5-11.

25. Dyrda S.G.. K voprosu o predmete munitsipal'nogo prava. // Administrativnoe i munitsipal'noe pravo.-2012.-№ 7.-C. 9-12.

26. Lapina E.B.. Gosudarstvennye zakupki gosudarstvennykh uslug. // Administrativnoe i munitsipal'noe pravo.-2013.-№ 9.-C. 901-909. DOI: .10.7256/19992807.2013.9.948
27. Kostennikov M.V. K voprosu o nekotorykh aktual'nykh problemakh administrativnogo prava // NB: Administrativnoe pravo i praktika administrirovaniya. - 2013. - 4. - C. 71 - 95. DOI: 10.7256/23069945.2013.4.8840. URL: http://www.e-notabene.ru/ al/article_8840.html

28. Dyrda S.G. K voprosu o predmete munitsipal'nogo prava // Administrativnoe i munitsipal'noe pravo. 2012. - 7. - C. $9-12$.

29. Kontsept «Voennaya bezopasnost'» i evolyutsiya voenno-politicheskogo mysh-leniya postsovetskoi Rossii // NB: Natsional'naya bezopasnost'. - 2012. 2. - C. 119 - 140. URL: http://www.e-notabene.ru/nb/ article_183.html 